\title{
DERMATOSES IN THE EARLY NEONATAL PERIOD: THEIR ASSOCIATION WITH NEONATAL, OBSTETRIC AND DEMOGRAPHIC VARIABLES
} Dermatoses no período neonatal precoce: associação com variáveis neonatais, obstétricas e demográficas

\author{
Elisa Maria Michels Krüger ${ }^{a}$ (1), Fernanda $\operatorname{Sinkos}^{a}$ (1), Julia Feldmann Uhry ${ }^{a}$ (1), \\ Julio Cesar Bezerra De Bonia ${ }^{0}$, Cristina Terumi Okamoto ${ }^{a}$ (D), \\ Kátia Sheylla Malta Purin ${ }^{a}$ (D), Renato Nisihara ${ }^{a *}$
}

\section{ABSTRACT}

Objective: To evaluate the prevalence of neonatal dermatoses in the early neonatal period and to associate them with neonatal, demographic and obstetric variables.

Methods: A cross-sectional study with neonates and their respective mothers, who were hospitalized in a public maternity hospital in Curitiba, PR, Brazil. Data collection was performed using information present in the medical records and a physical examination of the newborn during the period between April 2015 and May 2016.

Results: 350 neonates were evaluated. $54.8 \%$ were male, and 94.8\% (332/350) presented a dermatosis. Among them, 84.6\% had, concomitantly, two or more dermatoses. A total of 23 types of dermatoses were diagnosed. The most prevalent were: sebaceous hyperplasia (66\%); fluff (42.6\%); and salmon patches (41.4\%). The mean age of the mothers was $24.9 \pm 4.9$ years old, and they were predominately white $(57.7 \%)$. Vernix caseosa was associated with the female gender $(p=0.034)$. Nonwhite mothers were associated with genital hyperpigmentation ( $p=0.03$ ) and Mongolian spots ( $p=0.001$ ). Physiological flaking was associated with cesarean deliveries $(p=0.03)$ and a gestational age of over 40 weeks $(p=0.054)$. Salmon patches was associated with primiparity ( $p=0.0001)$.

Conclusions: There was a high prevalence of neonatal dermatosis in the studied population. Each newborn had, on average, three different dermatoses. Dermatosis in neonates was associated with primiparity, nonwhites, a gestational age of over 40 weeks, and the sex of the newborn.

Keywords: Dermatosis; Pediatrics; Infant, newborn.

\section{RESUMO}

Objetivo: Avaliar a prevalência de dermatoses no período neonatal precoce e associar sua ocorrência a variáveis neonatais, demográficas e obstétricas.

Métodos: Estudo transversal com neonatos e respectivas puérperas internados em alojamento conjunto de uma maternidade pública de Curitiba (PR). A coleta de dados foi realizada por meio de informações presentes nos prontuários e no exame físico do recém-nato durante o período de abril de 2015 a maio de 2016.

Resultados: Foram avaliados 350 recém-nascidos, 54,8\% do sexo masculino, e 332 (94,8\%) apresentaram dermatoses. Desses 332, $84,6 \%$ tiveram, concomitantemente, duas ou mais dermatoses. Diagnosticou-se o total de 23 tipos de dermatoses, sendo mais prevalentes: hiperplasia sebácea (66,6\%); lanugem (42,6\%); e mancha salmão (41,4\%). A média de idade das puérperas foi de $24,9 \pm 4,9$ anos, com predomínio de etnia branca (57,7\%). Vérnix foi associado a sexo feminino $(p=0,034)$. A etnia materna não branca associou-se à hiperpigmentação genital $(p=0,030)$ e mancha mongólica $(p=0,001)$. A descamação fisiológica associou-se ao parto cesáreo $(p=0,030)$ e à idade gestacional acima de 40 semanas $(p=0,054)$; e mancha salmão, à primiparidade $(p=0,0001)$.

Conclusões: Verificou-se alta prevalência de dermatose neonatal na população estudada, sendo cada recém-nascido acometido em média por três tipos. Houve associação da presença de dermatoses com primiparidade, mães não brancas, idade gestacional superior a 40 semanas e sexo do neonato.

Palavras-chave: Dermatoses; Pediatria; Recém-nascido.

*Corresponding author. E-mail: renatonisihara@gmail.com (R. Nisihara).

aniversidade Positivo, Curitiba, PR, Brazil.

Received on December 19, 2017; approved on April 02, 2018; available online on May 21, 2019. 


\section{INTRODUCTION}

The early neonatal period is marked by the newborn adapting to extrauterine life, with physiological changes that result because of changes involved with moving from the liquid uterine environment to the external dry environment. During this period, dermatological conditions may be present due to the peculiarities of neonatal skin. Its cutaneous constitution differs from adult skin because of its glandular and melanocytic immaturity, its thin layer thickness, and its biochemical composition, which alkalinizes the $\mathrm{pH}$. These anatomical and physiological factors make it predisposed to neonatal dermatoses (ND). Because of the benign and self-limiting physiological nature of most lesions, there is no need for any intervention. Avoiding excessive handling of the newborn is recommended because of the potential risk for iatrogenesis. ${ }^{1}$

The appropriate characterization of the highly prevalent NDs in the newborn population treated at our hospitals improves the differential diagnosis of pathogenic eruptions of vertical transmission that require intervention. ${ }^{2}$ In addition, the correct diagnosis reduces the need for dermatological outpatient clinics, where it is estimated that $30 \%$ of consultations deal with this condition. ${ }^{3}$ Recognizing NDs is essential to reassure parents about physiological skin changes and avoid unnecessary therapeutic measures. ${ }^{4}$

The present study had as its objectives to evaluate the prevalence of NDs in the early neonatal period and to verify associations between the presence of such changes with factors related to gestation and characteristics of the newborn (NB).

\section{METHOD}

The study was approved by the Committee of Ethics in Research (CEP) of the Hospital do Trabalhador and the Health Secretariat of Paraná (SES / PR), and was registered under the Certificate of Presentation for Ethical Assessment (CAAE) number 44236115.8.0000.5225.

The maternity hospital, Hospital do Trabalhador, was selected as a reference, given its high birth rate/year. Since the implantation of the Mãe Curitibana Program in 1999, it is a reference for 26 health units in the state capital.

The sample size was calculated based on the average of three thousand births per year in the hospital, totaling 350 newborns and 350 new mothers, and giving a sample power of over $95 \%$. It was a cross-sectional study carried out between April 2015 and May 2016, through the clinical evaluation of dermatological alterations in a consecutive sample of NBs up to seven days old. In addition, data were collected from the records of the newborn and the new mother with regard to birth conditions and gestational data. Both the newborn and the new mother were hospitalized in the maternity unit.
The criteria for inclusion were the following: NB of up to seven days of life and their respective mother; they agreed to and signed the free and informed consent form along with the person in charge. The exclusion criteria were: patients with incomplete data in their medical records; mucosal dermatoses and faneros; neoplastic and infectious dermatoses; postpartum women under 18 years of age; and patients admitted to the Intensive Care Unit (ICU).

All of the researchers were trained by an experienced dermatologist to inspect the skin of the NB, and were able to perform a dermatological diagnosis of the ND. In cases of doubt, photographs of the dermatosis were taken for further discussion and decision making. The diagnosis was exclusively clinical, and did not involve biopsy procedures. The diagnosed skin changes were grouped in the following categories, based on criteria of pediatric dermatology described by Hulsmann et al..$^{5}$ and Kane et al..$^{6}$ :

- General: vernix caseosa, fluff, sebaceous hyperplasia, miliaria crystalline, physiological flaking, neonatal cephalic pustulosis, neonatal toxic erythema.

- Local: diaper erythema, seborrheic dermatitis.

- Vascular: salmon patches, telangiectasia, marmoreal cutis, generalized erythema, plethora, acrocyanosis, childhood hemangioma.

- Pigmentation: Mongolian spots, hyperpigmentation of the genitalia, melanocytic nevus, café au lait spots.

The data obtained were arranged in Microsoft Excel spreadsheets, and the results were expressed as mean and standard deviation. The dichotomous variables were analyzed by the chisquare test and Fisher's exact test using the GraphPad Prism 5.0 statistical package. Values less than $5 \%$ were considered to be significant.

\section{RESULTS}

In total, 362 cases were evaluated. For 12 of them, the medical records were incomplete, and were excluded. Thus, a total of 350 new mothers and neonates were included. When evaluating data from the new mothers, the age range of 22-30 years old prevailed (53.1\%), with the mean age of the women studied being $24.9 \pm 4.9$ years old. Among the women evaluated, 202/350 (57.7\%) declared themselves to be white, $125 / 350$ (35.7\%) declared themselves to be brown and 23/350 (6.6\%) declared themselves to be black. With regard to the type of delivery, $260 / 350(74.3 \%)$ had a vaginal delivery and $90 / 350(25.7 \%)$ had a cesarean delivery. In the sample, $217 / 350(62 \%)$ were multiparous and $133 / 350(38 \%)$ were primiparous. 
Among the 350 newborns examined, 192 (54.8\%) were males and $236(67.4 \%)$ were between zero and one day old (mean 1.24 days). With regard to weight, 315 (90\%) were between 2,500 and 3,999 g, with a mean of 3,245.4 $4442.57 \mathrm{~g}$. Gestational age at the time of delivery for $98 \%$ of the sample was between 37 and 41 weeks.

The presence of ND was found in $94.8 \%$ of the evaluated $\mathrm{NBs}$, and in 295 (84.6\%) there was more than one type of cutaneous development. Twenty-five different types of ND were found, and their diagnostic frequency was 1,028. Figure 1 illustrates some of the ND found. In relation to the categories, the prevalence of the following were: general $(71.4 \%)$, vascular (19\%), pigment (7\%), local (1.9\%), malformation (0.19\%) and tocotraumatism $(0.28 \%)$. This amount was obtained by adding up the total number of dermatoses verified in the 332 affected $\mathrm{NB}$, resulting in an average of three concomitant neonatal dermatosis for each patient. No NB of the study needed additional treatment because of their dermatosis. The types of ND observed in the present study are described in Table 1 .

The prevalence of ND varied according to the sex of the newborn. Genital hyperpigmentation, one of the representatives of the pigment category, was significantly more present in males ( $\mathrm{p}<0.001)$. On the other hand, vernix caseosa was significantly more observed in females $(\mathrm{p}=0.033)$. For the other dermatoses, there was no significant difference between the sexes.

The delivery method and parity influenced the frequency of ND. There was a higher frequency of ND in the general, vascular and pigment categories in recent mothers with only one child. With regard to the delivery method, in the general and local categories, there was a higher prevalence of neonatal dermatoses in vaginal and cesarean birth infants, respectively. Data are shown in Table 2.

The dermatoses had different sites of development. Salmon patches affected $30 \%$ of cases and more than one anatomical region, with $62.8 \%$ in the eyelid and $28.3 \%$ in the glabellar region. Sebaceous hyperplasia was limited to the face, with $86.3 \%$ of cases in the nasal region. Table 3 shows the skin changes and the body sites where they were observed.

Through dichotomous statistical analysis, each neonatal, demographic and obstetric variable, listed in Tables 1 and 2, was assigned to each of the 23 neonatal dermatoses identified in the series. Table 4 shows the significant associations, demonstrating each variable that constituted a risk factor for the appearance of the specific neonatal dermatosis listed.

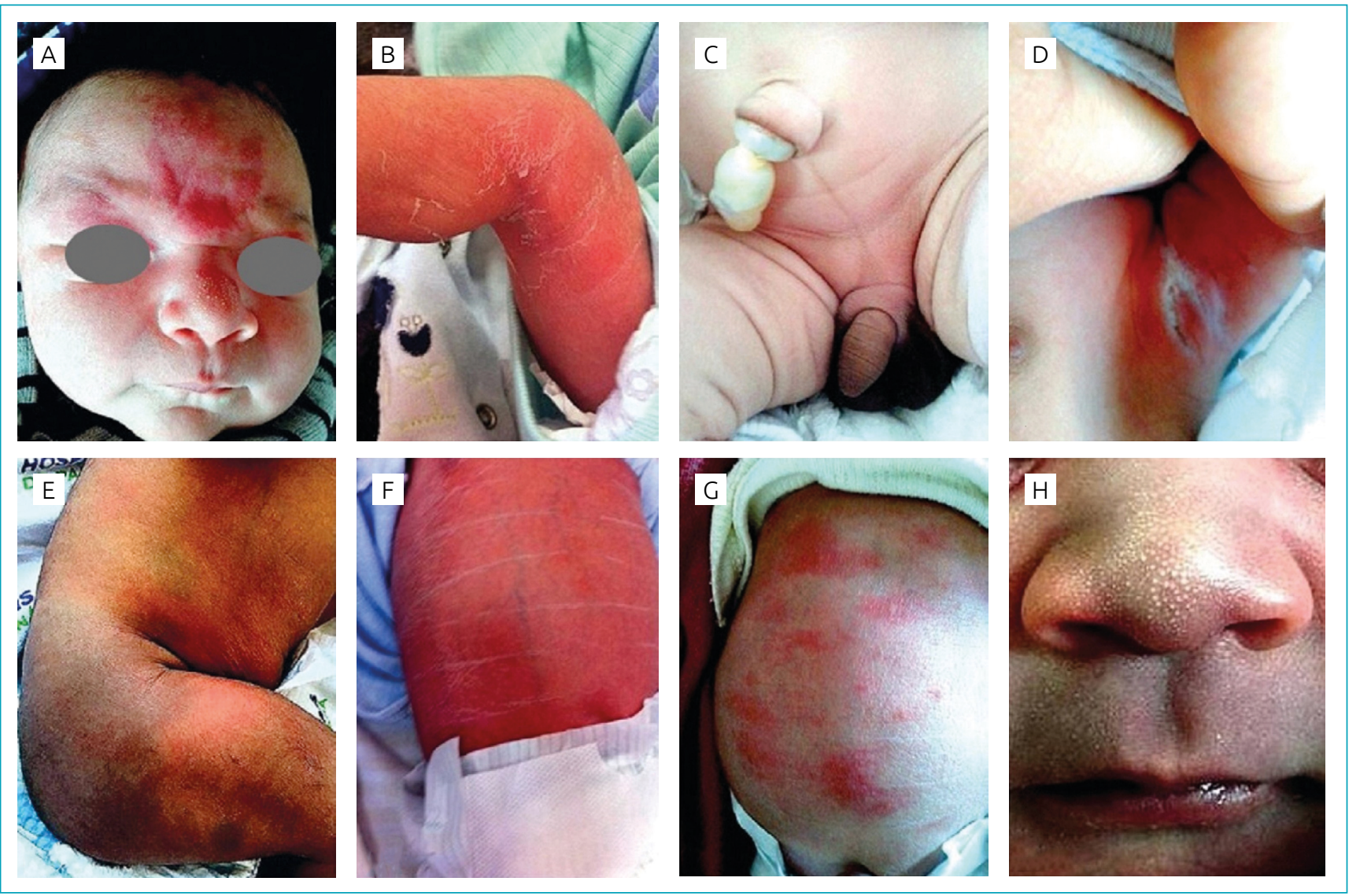

Figure 1 Neonatal dermatoses observed in the studied group. 
Table 1 Distribution of neonatal dermatoses according to the categories identified in the 350 newborns.

\begin{tabular}{|c|c|c|}
\hline Dermatosis by category & $\mathbf{n}$ & Frequency (\%) \\
\hline \multicolumn{3}{|l|}{ General } \\
\hline Sebaceous Hyperplasia & 233 & 66.6 \\
\hline Physiological flaking & 140 & 40 \\
\hline Fluff & 149 & 42.6 \\
\hline Vernix caseosa & 91 & 26 \\
\hline Crystalline miliaria & 89 & 25.4 \\
\hline Toxic erythema & 18 & 5.1 \\
\hline Neonatal cephalic pustulosis & 7 & 2 \\
\hline \multicolumn{3}{|l|}{ Local } \\
\hline Diaper егуthmea & 19 & 5.4 \\
\hline Seborrheic dermatitis & 1 & 0.3 \\
\hline \multicolumn{3}{|l|}{ Vascular } \\
\hline Salmon patches & 145 & 41.4 \\
\hline Telangiectasia & 18 & 5.1 \\
\hline Cutis marmorata & 9 & 2.6 \\
\hline Generalized erythema & 6 & 1.7 \\
\hline Childhood hemangioma & 3 & 0.8 \\
\hline \multicolumn{3}{|l|}{ Pigment } \\
\hline Genital hyperpigmentation & 39 & 11.1 \\
\hline Mongolian spots & 32 & 9.1 \\
\hline Melanocytic nevus & 2 & 0.8 \\
\hline Café au leite spots & 1 & 0.3 \\
\hline Total & 1,028 & \\
\hline
\end{tabular}

\section{DISCUSSION}

The high prevalence of ND and their multiple and concomitant form of development match what is said in the medical literature. In addition, they are intrinsically related to the ethnic, demographic and obstetric profiles of the populations studied. It is extremely important that, in addition to dermatologists, professionals directly involved in the primary care of newborns are able to diagnose these physiological changes. DN may occur because the cutaneous attachments that are still immature at birth gradually pass through a maturation process in the early neonatal period. As such, the skin plays a role in adapting to extrauterine life. ${ }^{4,7-7}$

At the national level, there are investigations with the neonatal population of Rio Grande do Sul, Rio de Janeiro, São Paulo and Pernambuco. ${ }^{7-10}$ The high frequency of ND observed in the present study (94.8\%) was similar to the other Brazilian studies. The rate of multiple cutaneous development (84.6\%) was also high, similar to the other studies in which it ranged from 48.1 to $87.9 \%{ }^{7,9,10}$ Therefore, it is common for newborns to have ND, mostly multiple and concomitant types.

Internationally, there are many studies on the subject. The prevalence of ND ranged from $34.7 \%{ }^{14}$ in a Pakistani study to $99.3 \%$ in Australia. ${ }^{15}$ Intermediate values were observed in India $(55.0 \%)^{3}$ and Turkey (67.3\%). ${ }^{16}$ The values that most approached our prevalence were those recorded in the Iranian $(96 \%)^{11}$ and Indian populations $(93.3 \%) .{ }^{12}$ The high prevalence

Table 2 Distribution of neonatal dermatoses by category according to parity and delivery method.

\begin{tabular}{|c|c|c|c|c|c|c|c|c|c|c|}
\hline \multirow[b]{2}{*}{ Dermatosis } & \multicolumn{3}{|c|}{ Parity } & \multirow[b]{2}{*}{$\%$} & \multirow[b]{2}{*}{ p-value } & \multicolumn{3}{|c|}{ Delivery method } & \multirow[b]{2}{*}{$\%$} & \multirow[b]{2}{*}{ p-value } \\
\hline & $\begin{array}{c}\text { Multiparous } \\
n=217\end{array}$ & $\%$ & $\begin{array}{c}\text { Primiparous } \\
n=133\end{array}$ & & & $\begin{array}{l}\text { Vaginal } \\
\mathrm{n}=260\end{array}$ & $\%$ & $\begin{array}{c}\text { Cesarean } \\
n=90\end{array}$ & & \\
\hline \multicolumn{11}{|l|}{ General } \\
\hline Sebaceous hyperplasia & 144 & 66.3 & 89 & 66.9 & 1 & 179 & 68.8 & 54 & 60 & 0.92 \\
\hline Physiological flaking & 88 & 40.5 & 52 & 39 & 0.91 & 104 & 40 & 36 & 40 & 1 \\
\hline Fluff & 84 & 38.7 & 65 & 48.8 & 0.27 & 109 & 41.9 & 31 & 34.4 & 0.42 \\
\hline Vernix caseosa & 51 & 23.5 & 40 & 30 & 0.33 & 73 & 28 & 18 & 20 & 0.27 \\
\hline Crystalline miliaria & 52 & 23.9 & 37 & 27.8 & 0.54 & 67 & 25.7 & 22 & 24.4 & 0.89 \\
\hline Toxic erythema & 13 & 5.9 & 5 & 3.75 & 0.46 & 11 & 4.2 & 7 & 7.7 & 0.27 \\
\hline \multicolumn{11}{|l|}{ Local } \\
\hline Diaper erythema & 8 & 3.6 & 11 & 8.2 & 0.09 & 12 & 4.6 & 7 & 7.7 & 0.29 \\
\hline Seborrheic dermatitis & 1 & 0.4 & 0 & 0 & 1 & 0 & 0 & 1 & 1.1 & 0.25 \\
\hline \multicolumn{11}{|l|}{ Vascular } \\
\hline Salmon patches & 62 & 28.5 & 83 & 62.4 & $<0.001$ & 107 & 41.1 & 38 & 42.2 & 0.91 \\
\hline Cutis marmorata & 4 & 1.8 & 5 & 3.7 & 0.31 & 7 & 2.6 & 2 & 2.2 & 1 \\
\hline Generalized erythema & 1 & 0.4 & 5 & 3.7 & 0.034 & 4 & 1.5 & 2 & 2.2 & 0 \\
\hline \multicolumn{11}{|l|}{ Pigment } \\
\hline Genital hyperpigmentation & 22 & 10.1 & 17 & 12.7 & 0.60 & 33 & 12.6 & 6 & 6.6 & 0.17 \\
\hline Mongolian spots & 13 & 5.9 & 19 & 14.2 & 0.023 & 26 & 10 & 6 & 6.6 & 0.40 \\
\hline
\end{tabular}


demonstrates that skin adaptation is an intrinsic phenomenon to human development, even despite ethnic differences and cutaneous peculiarities. ${ }^{11,17-19}$ Differences between ND data in different populations may occur due to methodological and ethnic-social variations, such as: sample size, term of the neonatal period when performing the examination, inclusion of pathological dermatoses, inclusion of mucosas/faneros and ethnic plurality. ${ }^{12}$ Sanitary infrastructure conditions are also highlighted, since in Indian regions, the prevalence of infectious parasitic dermatoses overlaps with physiological dermatoses. ${ }^{3}$

In quantitative terms, 23 types of dermatoses were diagnosed in the present study, a value similar to that described in the literature, which varied from 15 to $35.8,10,12$ The prevalence of the six dermatological categories were, in descending

Table 3 Distribution of dermatoses according to anatomical regions.

\begin{tabular}{|c|c|c|c|c|c|c|c|c|c|c|c|c|c|c|c|}
\hline Dermatosis & Total & $\begin{array}{l}\text { Front } \\
\mathrm{n}=492\end{array}$ & $\%$ & $\begin{array}{c}\text { Back } \\
\mathrm{n}=135\end{array}$ & $\%$ & $\begin{array}{c}\text { LL and } \\
\text { LLF } \\
\mathrm{n}=232\end{array}$ & $\%$ & $\begin{array}{l}\text { UL and } \\
\text { ULF } \\
\mathrm{n}=92\end{array}$ & $\%$ & $\begin{array}{l}\text { Torso } \\
\mathrm{n}=51\end{array}$ & $\%$ & $\begin{array}{c}\text { Genitals } \\
n=8\end{array}$ & $\%$ & $\begin{array}{l}\text { LBS } \\
n=29\end{array}$ & $\%$ \\
\hline $\begin{array}{l}\text { Sebaceous } \\
\text { Hyperplasia }\end{array}$ & 233 & 233 & 47.3 & 0 & 0 & 0 & 0 & 0 & 0 & 0 & 0 & 0 & 0 & 0 & 0 \\
\hline $\begin{array}{l}\text { Physiological } \\
\text { flaking }\end{array}$ & 194 & 23 & 4.6 & 4 & 2.9 & 97 & 41.8 & 29 & 31.5 & 3 & 5.8 & 0 & 0 & 0 & 0 \\
\hline Fluff & 196 & 11 & 2.2 & 108 & 80 & 45 & 19.3 & 42 & 45.6 & 1 & 1.9 & 0 & 0 & 0 & 0 \\
\hline $\begin{array}{l}\text { Vernix } \\
\text { caseous }\end{array}$ & 106 & 10 & 2 & 1 & 0.7 & 44 & 18.9 & 10 & 10.8 & 30 & 58.8 & 8 & 100 & 0 & 0 \\
\hline $\begin{array}{l}\text { Crystalline } \\
\text { miliaria }\end{array}$ & 120 & 53 & 10.7 & 7 & 5.1 & 20 & 8.6 & 1 & 1 & 9 & 17.6 & 0 & 0 & 0 & 0 \\
\hline $\begin{array}{l}\text { Toxic } \\
\text { erythema }\end{array}$ & 35 & 11 & 2.2 & 4 & 2.9 & 10 & 4.3 & 1 & 1 & 2 & 3.9 & 0 & 0 & 0 & 0 \\
\hline $\begin{array}{l}\text { Salmon } \\
\text { patches }\end{array}$ & 145 & 145 & 29.4 & 0 & 0 & 0 & 0 & 0 & 0 & 0 & 0 & 0 & 0 & 0 & 0 \\
\hline $\begin{array}{l}\text { Cutis } \\
\text { marmorata }\end{array}$ & 9 & 0 & 0 & 1 & 0.7 & 6 & 2.5 & 2 & 2.1 & 0 & 0 & 0 & 0 & 0 & 0 \\
\hline $\begin{array}{l}\text { Generalized } \\
\text { erythema }\end{array}$ & 36 & 6 & 1.2 & 6 & 4.4 & 6 & 2.5 & 6 & 6.5 & 6 & 11.7 & 0 & 0 & 0 & 0 \\
\hline $\begin{array}{l}\text { Mongolian } \\
\text { spots }\end{array}$ & 38 & 0 & 0 & 4 & 2.9 & 4 & 1.7 & 1 & 1 & 0 & 0 & 0 & 0 & 29 & 100 \\
\hline
\end{tabular}

LL: lower limb; LLF: lower limb fold; UL: upper limb; ULF: upper limb fold; LBS: lumbosacral.

Table 4 Significant associations between the dermatoses and obstetrical, puerperial and neonatal variables.

\begin{tabular}{|c|c|c|c|c|c|c|c|c|}
\hline Dermatosis & $\begin{array}{l}\text { Obstetric } \\
\text { profile }\end{array}$ & $\begin{array}{c}\text { OR } \\
\text { (p-value) }\end{array}$ & $\begin{array}{l}\text { Puerperal } \\
\text { profile }\end{array}$ & $\begin{array}{c}\text { OR } \\
\text { (p-value) }\end{array}$ & $\begin{array}{l}\text { Neonatal } \\
\text { profile }\end{array}$ & $\begin{array}{c}\text { OR } \\
\text { (p-value) }\end{array}$ & $\begin{array}{l}\text { Dermatologic } \\
\text { profile }\end{array}$ & $\begin{array}{c}\text { OR } \\
\text { (p-value) }\end{array}$ \\
\hline Salmon patches & Primiparous & $\begin{array}{c}21.8 \\
(p<0.001)\end{array}$ & & & & & & \\
\hline Physiological flaking & $\begin{array}{l}\text { Cesarean } \\
\text { birth }\end{array}$ & $\begin{array}{c}16,7 \\
(p=0.03)\end{array}$ & & & $\begin{array}{l}\text { IG }>40 \\
\text { weeks }\end{array}$ & $\begin{array}{c}0.6 \\
(p=0.054)\end{array}$ & & \\
\hline $\begin{array}{l}\text { Genital } \\
\text { hyperpigmentation }\end{array}$ & & & Non-white & $\begin{array}{c}2,1 \\
(p=0.03)\end{array}$ & Masculine & $\begin{array}{c}7.2 \\
(p<0.001)\end{array}$ & & \\
\hline Mongolian spots & & & Non-white & $\begin{array}{c}3,9 \\
(p<0.001)\end{array}$ & & & & \\
\hline Vernix caseous & & & & & Feminine & $\begin{array}{c}1,0 \\
(p=0.034)\end{array}$ & No flaking & $\begin{array}{c}1.9 \\
(p<0.001)\end{array}$ \\
\hline
\end{tabular}

OR: Odds Ratio; GI: gestational age. 
order: general (71.4\%), vascular (19\%), pigment (7\%), local $(1.9 \%)$, malformations $(0.19 \%)$ and tocotraumatism $(0.28 \%)$. The first three categories mentioned made up $97.4 \%$ of the 23 manifestations, so they should be a focus of attention for newborn skin. This pattern was repeated in an Indian study, ${ }^{18}$ in which general dermatoses were among the 10 most prevalent diagnoses. Dermatoses of the general and pigment categories were the most prevalent ${ }^{9,10,19,20}$ in national and international studies. Our study corroborates these findings, since, of the five predominant types of $\mathrm{ND}$, four belonged to the general category. There is no consensus in the literature regarding the most common dermatosis in the general category, since in each study analyzed, one of the following DNs was cited as most prevalent: flaking, ${ }^{19}$ toxic erythema, ${ }^{3}$ hyperplasia sebaceous ${ }^{9}, 17,21$ and fluff. ${ }^{8,9}$ There was agreement between our study and others when comparing the vascular and pigment categories, taking into account that the salmon patches ${ }^{9,19,21}$ and Mongolian spots ${ }^{9,14,20,21}$ were, respectively, the most common. There was disagreement with regard to the pigmentary dermatoses: in our study, genital hyperpigmentation prevailed, and in the others, Mongolian spots was the most represented in the category. ${ }^{914.20}$

Sebaceous hyperplasia had a similar rate as in the literature $^{11,14,19,21}$ and was the most prevalent in the study. The development and function of the sebaceous gland in the fetus and neonate are regulated by maternal androgen and the synthesis of endogenous steroids, which lead to increased sebaceous excretion within a few hours after birth. This fact can cause excessive proliferation and superficial visualization at the beginning of extrauterine life. ${ }^{22}$ There was no statistical significance between sebaceous hyperplasia and maternal gestational intercurrences, which differs from other studies. ${ }^{11}$ Although reported as risk factors, in our study, multiparity ${ }^{20}$ and males were not predisposed to dermatosis.

Salmon patches (a type of vascular capillary malformation) has a pinkish-reddish tint, accentuates crying, and disappears after digital pressure. As found in $30 \%$ of the sample, it commonly affects more than one site, ${ }^{23}$ concentrating in the eyelid and glabellar region, which is similar to the findings of Indian research. ${ }^{17}$ Salmon patches is considered the main vascular dermatosis, and the reported frequency is between 20 and $28 \%{ }^{8,12,17,21,23,24}$ In our sample, such DN was present in $41.4 \%$ of NB, which higher than that observed in other populations. Some authors have described multiparity and being male as risk factors for ND. However, this was not observed in our study. On the other hand, primiparity made newborns predisposed to ND, doubling its chance of appearance. Differing from other authors, ${ }^{8,25}$ there was no association between maternal age above 35 years old and the female sex.
Mongolian spots are a hyperpigmentation of blue-gray tones that arise from the migratory flow of melanocytes during the embryonic stage. ${ }^{5,6,26,27}$ The wide range of this DN's prevalence (between 20 and $89 \%$ ) reflects the ethnic differences between countries, since it has a higher frequency in populations that have skin with a higher phototype (from 72 to $89 \%) .3,17,19$ The Mongolian spots in the present study had a higher incidence in males in the lumbosacral region, and were associated with neonates of non-white new mothers $(\mathrm{p}=0.0005 ;$ Odds Ratio $-\mathrm{OR}=3.9)$, which is in agreement with other studies. ${ }^{8,17,16,26,27}$ It is worth noting the high rate of black and brown women $(42.3 \%)$ in our sample. This is different from the census figures that come from the Brazilian Institute of Geography and Statistics (Instituto Brasileiro de Geografia e Estatistica - IBGE) for the capital city of the state of Paraná, in which the percentage is $23 \% .{ }^{28}$ Seventy-seven percent of the population of Curitiba and the surrounding region is white. ${ }^{28}$ One explanation for this finding may be the great migratory flow of Haitians to the capital of Paraná, which has occurred in the last decade. Currently, according to IBGE data, the number of Haitians living in Curitiba and the metropolitan region is estimated at 4,000 people..$^{29}$ Haitian pregnant women are referred to the Hospital do Trabalhador because they have available beds and specific triage procedures for early care obstetrics. It is a reference hospital for 26 health units in the Paraná State capital. ${ }^{29}$

Transient hyperpigmentation of genitalia occurs when the melanocyte stimulating hormone is exacerbated during intrauterine life, increasing the number of dendritic cells containing melanin granules and reducing the action of melanophages. The prevalence observed in the present study was similar to that of the Gaucho study (18.9\%). ${ }^{6}$ Furthermore, the Mongolian spots prevailed in $\mathrm{NB}$ of nonwhite recent mothers, and was associated with males, which corroborates data from the literature. ${ }^{6,13,14,20}$

Diaper dermatitis occurs when the perineal epidermal barrier is changed. It is influenced by cutaneous care such as: local occlusion, fecal enzymes, topical products and friction during local hygiene. ${ }^{24,30}$ Its prevalence in our study was similar to that in others. ${ }^{11,18,20,30}$ Taking into account that more than half of the newborns wearing diapers had at least one episode until their weaning, ${ }^{30}$ we considered the prevalence of $5.4 \%$ to be high since the average days of life (1.24) and the period of analysis (seven days) were short.

The prevalence of physiological flaking described in the literature ranges from 1.9 to $83 \%$. In our sample, the diagnosis was made in $40 \%$ of the NBs, coinciding with other investigations. ${ }^{11,12,17}$ We observed an association with delivery method, since having a cesarean section and a gestational age 
over 40 weeks increased the chance of occurrence. There was no association with neonatal sex and parity.

Vernix caseosa was diagnosed in $26 \%$ of the studied NB, and the frequency described by other authors ranged from 7.7 to $49.2 \% .^{17,31}$ It has been shown, as well as in other investigation ${ }^{31}$ that the absence of vernix caseosa indicated a predisposition for flaking $(\mathrm{p}<0.001 ; \mathrm{OR}=1.9)$. Biochemical analyzes detected a greater amount of amino acids in areas of skin with vernix, conferring more hydration of the skin of the NB and preventing flaking. ${ }^{32}$ In addition, a higher prevalence was observed in females $(\mathrm{p}=0.034 ; \mathrm{OR}=1.7)$. Vernix is an indication of fetal maturity and epidermal synthesis because the levels of its production, along with that of ceramides, rise between 39 and 40 weeks. ${ }^{33-35}$ Although described, ${ }^{17}$ the association of vernix and gestational age over 40 weeks was not observed in our study. This is because, from this intrauterine stage, the vernix can detach itself in the amniotic fluid, before birth.

The neonatal toxic erythema is characterized as a sterile erythematous halo. They are single or multiple papules that are predominate on the face, torso and extremities. ${ }^{2,5,36}$ Despite its low prevalence, it is important to identify it, because it is one of the differential diagnoses of candidiasis, genital herpes and syphilis. Some studies point to a frequency between 1.3 and $54 \%,{ }^{8,11-13,21,36}$ and in our study the rate was $5.1 \%$. Contrary to other studies, there was no association of neonatal toxic erythema with sex, type of delivery or parity. ${ }^{8,12,16,17}$

In the present investigation, there was a high prevalence of fluff $(42.6 \%)$, higher than that described in the literature (7-25.7\%). It is probable that this fact is due to the composition of the sample, with $98 \%$ of the newborns being full-term, considering that in this group, there is a predominance of $\mathrm{DN} .{ }^{12}$
However, there is controversy regarding this topic. ${ }^{8,12}$ Although the male gender and adequate birth weight have been associated together, ${ }^{12,20}$ the present study did not find this association.

The limitations of the study are specific to cross-sectional research. Only a follow-up with the NB could confirm that all of dermatoses would in fact disappear within a few days. The dermatoses could have been confused with one another, but in these cases, the researchers relied on the opinion of an experienced dermatologist to confirm them.

This study also highlights the need for pediatric assistants, those who care first for the NB, to have significant knowledge of the physiological skin changes that are most prevalent in this population, so they can reassure the parents, and convey confidence that the baby has a dermatosis that will disappear on its own and will not require a specialist or the use of medication.

Finally, in this investigation, there was a high prevalence of ND - each NB was affected by three neonatal dermatoses on average. Regarding the variables inherent to gestation, there was a significant association between primiparity and salmon patches. In addition, there was one between nonwhite mothers and their child having genital hyperpigmentation and Mongolian spots. With regard to the newborns, a significant association was found between gestational age greater than 40 weeks and physiological flaking; genital hyperpigmentation and male sex; and vernix caseosa and the female sex.

\section{Funding}

This study did not receive funding.

\section{Conflict of interests}

The authors declare no conflict of interests.

\section{REFERENCES}

1. Fernandes JD, Machado MC, Oliveira ZN. Children and newborn skin care and prevention. An Bras Dermatol. 2011;86:102-10.

2. Ghosh S. Neonatal pustular dermatosis: An overview. Indian J Dermatol. 2015;60:211.

3. Jawade SA, Chugh VS, Gohil SK, Mistry AS, Umrigar DD. A clinico-etiological study of dermatoses in pediatric age group in tertiary health care center in South Gujarat region. Indian J Dermatol. 2015;60:635.

4. Lobo I, Machado S, Selores M. Alterações cutâneas fisiológicas e transitórias do recém-nascido. Rev Nascer \& Crescer. 2009;18:19-24.

5. Hulsmann AR, Orange AP. Education paper: neonatal skin lesions. Eur J Pediatr. 2014;173:557-66.
6. Kane KS, Ryder JB, Johnson RA, Baden HP, Stratigos A. Color atlas and synopsis of pediatric dermatology. Nova York; McGraw-Hill; 2002.

7. Almeida JRP, Alchorne MMA, Rozman MA. Incidência de dermatoses em neonatos de enfermaria para gestantes de risco em hospital público. Einstein. 2010;8:143-8.

8. Reginatto FP. Prevalência e caracterização das afecções cutâneas neonatais em maternidades de Porto Alegre [PhD thesis]. Porto Alegre (RS): Universidade Federal do Rio Grande do Sul; 2015.

9. Bauk VO. Estudo Clínico das Dermatoses do Recém-nascido na Maternidade Escola da Universidade Federal do Rio de Janeiro [master's thesis]. Rio de Janeiro (RJ): Universidade Federal do Rio de Janeiro; 2006. 
10. Ferreira AS, Guerra AL, Javorski M, Bonfim SF, Leal LP, Silva TA. Lesion of skin in newborns and infants. Rev Esc Enferm UERJ. 2013;21:208-15.

11. Moosavi Z, Hosseini T. One-year survey of cutaneous lesions in 1000 consecutive Iranian newborns. Pediatr Dermatol. 2006;23:61-3.

12. Sadana DJ, Sharma YK, Chaudhari ND, Dash K, Rizvi A, Jethani S. A clinical and statistical survey of cutaneous changes in the first 120 hours of life. Indian J Dermatol. 2014;59:552-7.

13. Shajari $H$, Shajari A, Habiby NS. The incidence of birthmarks in Iranian neonates. Acta Med Iranica. 2007;45:424-6.

14. Javed M. Clinical spectrum of neonatal skin disorders at Hamdard University Hospital Karachi, Pakistan. Our Dermatol Online. 2012;3:178-80.

15. Rivers JK, Frederiksen PC, Dibdin C. A prevalence of dermatosis in the Australian neonate. J Am Acad Dermatol. 1990;23:77-81.

16. Ekiz O, Gül Ü, Mollamahmutoğlu L, Gönül M. Skin findings in newborns and their relationship with maternal factors: observational research. Ann Dermatol. 2013;25:1-4.

17. Haveri FT, Inamadar AC. A cross-sectional prospective study of cutaneous lesions in newborn. ISRN Dermatol. 2014;20:360590.

18. Jain N, Rathore BS, Agarwal AK, Bhardwaj A. Cutaneous lesions in neonates admitted in a tertiary setup neonatal intensive care unit. Indian J Pediatr Dermatol. 2013;14:62-7.

19. Ferahbas A, Utas S, Akcakus M, Gunes T, Mistik S. Prevalence of cutaneous findings in hospitalized neonates: a prospective observational study. Pediatr Dermatol. 2009;26:139-42.

20. Dash K, Grover S, Radhakrishnan S, Vani M. Clinical epidemiological study of cutaneous manifestations in the neonate. Indian J Dermatol Venereol Leprol. 2000;66:26-8.

21. Chaithirayanon S, Chunharas A. A survey of birthmarks and cutaneous skin lesions in newborns. J Med Assoc Thai. 2013;96:S49-53.

22. Tagliolatto S, Alchorne MM, Enokihara M. Hiperplasia sebácea cutânea: estudo piloto para a correlação da doença com hormônios androgênios. An Bras Dermatol. 2011;86:917-23.

23. Gontijo B, Pereira LB, Silva CM. Vascular malformations. An Bras Dermatol. 2004;79:7-25.
24. Lupi O, Cunha PR. Rotinas de diagnóstico e tratamento da Sociedade Brasileira de Dermatologia. $2^{\text {a }}$ ed. São Paulo: AC Farmacêutica; 2012.

25. Monteagudo B, Labandeira J, León-Muiños E, Carballeira I, Cabanillas M, Suárez-Amor Ó, et al. Frequency of birthmarks and transient skin lesions in newborns according to maternal factors (diseases, drugs, dietary supplements, and tobacco). Indian J Dermatol Venereol Leprol. 2011;77:535.

26. Gupta D, Thappa DM. Mongolian spots: how important are they? World J Clin Cases. 2013;1:230-2.

27. Gupta D, Thappa DM. Mongolian spots. Indian J Dermatol Venereol Leprol. 2013;79:469-78.

28. Gazetadopovo.com.br. [homepage on the Internet]. Curitiba descobre seus negros [cited 2017 May 16]. Available from: http://www.gazetadopovo.com.br/blogs/caixa-zero/curitibadescobre-seus-negros/

29. Curitiba.pr.gov.br [homepage on the Internet]. Sine Curitiba é porta de entrada para haitianos no mercado de trabalho [cited 2017 May 16]. Available from: http://www.curitiba. pr.gov.br/noticias/sine-curitiba-e-porta-de-entrada-parahaitianos-no-mercado-de-trabalho/34671

30. Telofski LS, Morello AP 3rd, Mack Correa CM, Stamatas $\mathrm{GN}$. The infant skin barrier: can we preserve, protect, and enhance the barrier? Dermatol Res Pract. 2012;2012:198789.

31. Monteagudo B, Labandeira J, León-Muiños E, Romarís R, Ramírez-Santos A, González-Vilas D, et al. Influence of neonatal and maternal factors on the prevalence of vernix caseosa. Actas Dermosifiliogr. 2011;102:726-9.

32. Visscher MO, Utturkar R, Pickens WL, LaRuffa AA, Robinson $M$, Wickett RR, et al. Neonatal skin maturation - vernix caseosa and free amino acids. Pediatr Dermatol. 2011;28:122-32.

33. Checa A, Holm T, Sjödin MO, Reinke SN, Alm J, Scheynius A, et al. Lipid mediator profile in vernix caseosa reflects skin barrier development. Sci Rep. 2015;5:15740.

34. Míková R, Vrkoslav V, Hanus R, Háková E, Hábová Z, Doležal A, et al. Newborn boys and girls differ in the lipid composition of vernix caseosa. PLoS One. 2014;9:e99173.

35. Singh G, Archana G. Unraveling the mystery of vernix caseosa. J Indian Dermatol. 2008;53:54-60.

36. Reginatto FP, Villa DD, Cestari TF. Benign skin disease with pustules in the newborn. An Bras Dermatol. 2016;91:124-34. 